POLITYKA ENERGETYCZNA - ENERGY POLICY JOURNAL

$2019 \downarrow$ Volume $22 \uparrow$ Issue $1 \uparrow 19-38$

DOI: $10.33223 /$ epj/103667

Ewelina KOCHANEK ${ }^{1}$

\title{
Regional cooperation on gas security in Central Europe
}

ABSTARCT: The role and importance of energy security increases with the development of civilization, whose inherent element has become the demand for energy and its carriers. The article discusses the issue of cooperation in the field of energy security in Central Europe at the moment of finishing work on the North-South Corridor, which changes the existing gas architecture in the region. In order to better understand the situation in the region, the energy systems of the Visegrad Group countries, identical to the Central European region, have been analysed, according to the definition of the World Bank and OECD. Considering the historical and geopolitical connections of the Visegrad Group's fate, it is important to create a common gas market. The physical interconnection of gas systems greatly increases energy security in this region. Moreover, thanks to the construction of LNG terminals in Poland and Croatia, it will be possible to diversify not only the routes, but also the sources of supply of this important raw material.

KEYWORDS: energy security, energy policy of the UE and Visegrad Group, gas market

\section{Introduction}

Since the beginning of statehood, the concept of own security has been the most important item on a state's foreign policy agenda. Along with the changing global order, new concepts

\footnotetext{
${ }^{1}$ Political and European Science Institute, University of Szczecin, Szczecin, ORCID: 0000-0001-8155-9209; e-mail: ewelina.kochanek@usz.edu.pl
} 
of security have also emerged, the implementation of which has guaranteed the survival of the nation. In the $21^{\text {st }}$ century, the key challenge for each state is to ensure a sufficiently high level of energy security. Energy is essential for the proper functioning of modern economies. The efficient and stable operation of the energy sector is an extremely important factor determining both economic and social development. Unfortunately, energy security is very dynamic, it is not given once and for all, and we need to take continuous measures to maintain it. Due to the tightening of local or regional ties between states, maintaining energy security becomes more difficult, and issues related to the aspect of energy security are solved together, which is not always beneficial for all members of a given group.

The aim of the article is to present cooperation in the field of energy security in Central Europe and to try to answer the question whether and how the integration of the markets in the examined area will contribute to the strengthening of regional energy security. In order to achieve this goal, the following research problems should be analyzed:

$\checkmark$ What is the energy situation of individual Central European countries?

$\checkmark$ What impact does the existing and planned energy infrastructure have on the security of the region?

$\downarrow$ What factors determine energy security in the analyzed region?

For the purpose of this publication, Central Europe is understood as a synonym of the Visegrad group to which the following countries belong: Czech Republic, Poland, Slovakia and Hungary. This grouping, also known as the V4, was established at the beginning of the 1990s and its main objective was to cooperate with the European Union and NATO within the framework of member states' accession to the structures of these organizations. The common feature of the Visegrad Group countries is the history of belonging to the Eastern bloc and the legacy of the socialist energy system. These countries were the most important importers of Russian energy resources during the whole period of socialism. For this reason, the transmission system for both gas and oil in these countries was built latitudinally, which allowed for the reception of hydrocarbon supplies only from the east. After the collapse of the USSR, for about 20 years, the V4 countries were still dependent almost $100 \%$ on imports from Russia. It was only in the last decade that work began on changing the energy dependence on the Russian superpower.

\section{Energy situation of the Central European countries}

The last twenty years have been a time of rapid transformations and quite rapid economic growth for the Central European region. It is also worth noting that the V4 countries developed faster than the Euro zone countries, especially in the years 2001-2007. The process of modernization at practically all levels was mainly financed by the EU cohesion policy funds (Popławski 2016).

The similarity of energy problems and geographical proximity led the Visegrad countries to intensify their cooperation, in particular by agreeing on a common strategy for the security of the 
natural gas supply and regional crisis planning in this area. The Czech Republic and Slovakia are most interested in integrating with the Western European gas market, as they have more system interconnections with the reverse flow with Western Europe than the other two V4 countries (Ascari 2013).

Central Europe is not a region generously endowed by nature with energy carriers, especially in those desired today: natural gas and oil. Referring to the region's energy consumption to rich Western Europe, one fundamental conclusion can be drawn that the region is not a significant energy consumer. Solid fuels are the largest source of energy in the grouping under analysis. However, these countries differ in the type and degree of use of energy carriers and the level of import dependence. The energy balance of Poland and the Czech Republic is dominated by solid fuels, while natural gas is the main primary energy carrier in Hungary and Slovakia. All the V4 countries except for Poland have in their energy balance from nuclear energy. The common feature of the group is a small production of energy from renewable sources. In order to better understand the subject, it is necessary to analyze the situation in the energy sector of the V4 countries.

\subsection{The Czech Republic}

Of all the former Eastern Bloc countries, the Czech Republic is one of the most developed and industrialized economies in Central Europe. Like the other V4 countries, it is a significant producer of solid fuels (brown coal, hard coal and lignite) in Europe. The most important, and at the same time, the greatest energy potential for the Czech economy is brown coal, the deposits of which are located in the northern and north-western part of the country, in the North Bohemian Basin (the largest in terms of output - in total as much as $80 \%$ of total lignite output) and in the Sokołowski Basin. Brown coal reserves are estimated at approximately 737 million tons of economically viable coal. Over the last 20 years, the output of this raw material has been gradually decreasing. Since 2008 , there has been a drop in production, which has been deepening every year and currently amounts to 42 million tons of this raw material (Euracoal 2018).

Another fuel which plays a much smaller role in the production of electricity in this country is hard coal. It is mined in the Ostrava-Karviná mining district. As in the case of brown coal, the production of this energy carrier is also on a downward trend. In 1990 production amounted to 23.19 million tons and in 2017 there was a decrease to 8 million tons (Czech Republic Energy Overview 2018).

Due to the shortage of the main hydrocarbons, the Czechs turned to nuclear energy. The era of the nuclear energy in the former Czechoslovakia came as a result of Russian activities in this area. The Czech industry was a significant producer of parts for reactors of nuclear power plants, which were built in the countries of the Eastern bloc. The first facility in this country was the Dukovany power plant, which was opened in 1979. In 2000, the second power plant, Temelin, was opened. There are four units currently operating in the Ducovany power plant with a total installed capacity of $2040 \mathrm{MW}$ and two units in the Temelin power plant with an installed capacity 
of more than 2100 MW (CEZ, a. s. - Nuclear Power Plants 2018). According to the assumptions of the Czech energy policy of 2014, the construction of additional nuclear power units, which are to be built by 2035, is planned. In addition, the Czechs intend to extend the service life of the existing power units at the Dukovany power plant from 50 to even 60 years. In the long term, nuclear energy can account for more than $50 \%$ of electricity production, replacing a large part of coal-fired power generation.

The new energy strategy of the Czech Republic adopted by the parliament of the Czech Republic in May 2015 provides for limiting coal in the energy mix. Over the next few years it is expected to fall to $21 \%$. In the following years, brown coal mining will also decrease, which is limited by territorial ecological limits. Hard coal for the power industry will be imported in its entirety. The decrease in electricity production from coal is to be compensated by a reduction in electricity exports. Thanks to the energy obtained from nuclear energy, the Czech Republic is a large exporter of electricity (in 2014 exports amounted to 1/3 of annual production) (State Energy Policy... 2014).

The Czech Republic is fully dependent on imports of natural gas. This raw material is extracted in the southern part of Moravia in residual quantities, in 2015 it was only 247 million $\mathrm{m}^{3}$ or $2 \%$ of the domestic demand (the annual consumption of natural gas is about 8.2 billion $\mathrm{m}^{3}$ ). Due to low own resources and high domestic demand, the supply of this raw material is entirely dependent on imports. It is based on a transit pipeline from Russia to Western Europe. Imports of gaseous fuel amount to over 7.9 billion $\mathrm{m}^{3}$. The diversification of gas suppliers is spread between the countries: Russia $-60 \%$ and Norway $-40 \%$. The continuity of seasonal gas offtake in the country in question is ensured by 9 tanks with a total capacity of 4 billion $\mathrm{m}^{3}$, which enable the storage of almost $50 \%$ of annual gas consumption (IEA 2017).

The gas system is connected to the systems of neighboring countries (Germany, Poland and Slovakia), which proved particularly important at the time of the limited transit of Russian gas through Ukraine. The input capacity of the gas pipelines on the eastern border of the country is 51 billion $\mathrm{m}^{3}$ per year, while in the west it is 29 billion $\mathrm{m}^{3}$. The launch of the Gazela gas pipeline in 2012, with a capacity of 30 billion $\mathrm{m}^{3} /$ year, made it possible to connect it with the Opal pipeline, which transports Russian gas from Nord Stream via eastern Germany to the south, with the Megal pipeline, which transports the raw material through southern Germany to France. What is essential for the security and reliability of gas supplies to domestic customers is, firstly, the fact that at several nodes, the Gazela pipeline is connected to the Czech transport system, which may constitute an alternative supply channel should there be any recurring problems with the supplies provided by Ukraine. Moreover, thanks to this interconnection, more Russian gas enters the Czech Republic via Germany than via Slovakia from the Brotherhood gas pipeline. In 2011, work was also completed on the construction of the first interconnector connecting the Czech Republic and Poland with an annual capacity of 0.5 billion $\mathrm{m}^{3}$. There are also plans to build a second interconnector with a capacity of 6.5 billion $\mathrm{m}^{3}$. The aforementioned investments form part of the north-south corridor in Central and Eastern Europe. Other alternative gas pipelines are also planned: the 14 billion $\mathrm{m}^{3}$ Moravia pipeline, which will be completed in 2019 at the earliest, and the BACI interconnector, which will connect the Czech gas system with the Austrian system (Gas Networks 2018). 
As in the case of gas, there are no significant crude oil reserves in the Czech Republic. Small quantities of this hydrocarbon are located in the western part of Moravia. In 2014, 154,000 tons of crude oil were produced from domestic sources, which corresponds to $3 \%$ of the domestic demand. Unfortunately, the remaining quantities of crude oil must be ensured by importing them. Russia and Azerbaijan are the leading suppliers of crude oil. Other less significant exporters are: Kazakhstan, Norway and Libya. As part of occasional purchases of this raw material, the marginal suppliers of crude oil are: Italy, Syria, Nigeria and Algeria (MPO 2016).

The Druzhba oil pipeline is the main oil pipeline supplying crude oil to the Czech Republic. In 1995, the directions of crude oil supply diversified with the launch of the IKL pipeline, which connects the Czech Republic with the Transalpine pipeline (TAL), which transports crude oil from an oil terminal located in Trieste in Italy.

The IKL pipeline mainly supplies low-sulphur crude oil, the so-called sweet oil, which is processed in the Kralupy refinery. Recently, this oil pipeline has mainly been used to transport oil from the Russian Federation. The capacity of crude oil imports transported by the Druzhba oil pipeline from the east is about 10 million tons per year, while the IKL pipeline from the west is about 11 million tons per year (State Energy Policy... 2014).

The conditions for the use of renewable forms of energy in the Czech Republic are not very favorable. This is due to poor wind conditions, less insolation and the lack of geothermal sources. In the total primary energy balance, the share of RES in gross final energy consumption in 2017 was $13.5 \%$. Therefore, it should be emphasized that this is an effect achieved through the production of energy in hydroelectric power plants and biomass. Currently, in addition to hydroelectric power plants, biomass has the largest share in the production of Czech "green" energy. In 2040, the country is expected to approach the maximum level estimated at over $21 \%$ (Czech Republic Energy Overview 2018). Moreover, the Czechs do not expect any major problems with reducing $\mathrm{CO}_{2}$ emissions according to EU climate policy indicators.

\subsection{Poland}

Poland, like other countries of the region, has fossil resources. Unfortunately, these fuels, which are the most desirable in today's world (i.e. natural gas and crude oil), occur in this region only in small amounts. On the other hand, Eastern European countries have been generously endowed with coal by nature. In the Polish energy balance, hard coal occupies a leading position, as it satisfies $60 \%$ of the country's energy demand. The largest hard coal reserves can be found in the Upper Silesian region: The Upper Silesian Basin $(80.8 \%$ of the national output) and the Lublin Basin. Poland ranks 9th in terms of hard coal mining in the world. The output of this energy raw material in Poland is characterized by a downward trend; in the years 1990-2017 it dropped almost 62\% from about 152 to 57 million tons (Geoportal 2017). This phenomenon is caused by the switch to other energy sources, the closure of unprofitable mines and environmental requirements imposed by the European 
Union, which require the construction of costly and energy-consuming installations aimed at reducing air pollution.

Brown coal is the second most important primary energy carrier. Three brown coal basins have developed in Poland:

$\downarrow$ Bełchatów basins (the largest, more than a half of domestic output);

$\checkmark$ Konińsko-Tureckie (more than $30 \%$ of domestic output);

$\checkmark$ Turoszów (less than $20 \%$ of domestic output).

The largest output of brown coal deposits is in the Bełchatów mine. Brown coal mining has not undergone drastic changes and amounts to approx. 64 million tons. It is worth mentioning that Poland is one of the world's top ten producers of brown coal.

Crude oil is another energy raw material, which is included in Poland's energy balance. It is worth adding that the tradition of Polish crude oil mining has a long history, as its commercial output began in the middle of the 19th century in the south-eastern part of the country (today's Podkarpackie Province). There are many oil fields in this country, but most of them are small or almost completely exhausted (Podkarpacie). The largest and most efficient crude oil fields are located in the Polish Lowlands. The second important region for Poland is the Baltic Sea shelf. Polish crude oil reserves currently amount to approximately 24 million tons. Domestic production is small and in 2017 amounted to 940 thousand tons per year, which, in total, constituted only $5 \%$ of annual crude oil consumption. The Polish crude oil market is therefore a deficit market, which for many years has been characterized by a high share of imports in fuel consumption. Currently, $95 \%$ of crude oil is imported, $77.2 \%$ of which is Russian oil (POPIHN 2017). Crude oil is transported to Poland via the Druzhba pipeline, but deliveries of this oil can also be made by sea through the oil terminal in Gdansk, in the event of closure or limitation of pipeline deliveries of Russian oil. The oilport in Gdańsk serves as an alternative infrastructure for crude oil supplies to our country. Recently, its reloading capacity has increased and currently amounts to 40 million tons of crude oil and fuels annually, which allows the domestic demand for crude oil by sea to be fully secured. In 2013, the construction of a storage and reloading base for crude oil, its products and chemicals with a total capacity of 700,000 tons, including 400,000 tons for crude oil and 300,000 tons for other petroleum products, commenced. The first stage of the investment concerning crude oil tanks has been completed. In the second stage, the investment will be connected to the national transmission network.

The oil pipeline system is an extremely important element of the energy infrastructure. The international Druzhba pipeline was built in the 1960s. The Polish section of the pipeline is $670 \mathrm{~km}$ long and plays a significant role in Russian oil exports. Currently, 30\% of the crude oil exported by Russia flows through the pipeline, however, only a part of the crude oil remains in Polish refineries, the remaining amount goes to German customers and to Oilport in Gdańsk, from where it is transported to final customers. The network of pipelines in Poland has a total of about 2500 kilometers and is formed by branches from the Druzhba pipeline. What is important is that they are included in the European pipeline network (Small Statistical Year 2017).

In Poland, just like in the world, the role of natural gas as an energy carrier is growing, although these changes do not include electricity generation to a large extent due to the existing 
generation infrastructure in Poland aimed at generating energy from hard coal and brown coal. The demand for gas in Poland is characterized by an upward trend; this is related not only to new investments, but also to the modernization of industrial plants, departing from traditional power supply methods, which are the aftermath of the introduction of the climate and energy package by the European Commission in March 2007. The production of natural gas in Poland in the amount of 4.2 billion $\mathrm{m}^{3}$ (2017) is insufficient to cover the total demand for this raw material. The largest deposits of this raw material are located in the Wielkopolska Lowland, Western Pomerania and the foothills of the Carpathians.

The situation on the natural gas market is much better than in the case of crude oil, as $1 / 4$ of the gas consumed in Poland comes from domestic deposits and the rest is imported. Russia has been the main supplier of this hydrocarbon to Poland for many years. In 2017, 9.7 billion $\mathrm{m}^{3}$ of natural gas came from Russia, which accounted for approximately $71 \%$ of imports. The LNG terminal in Świnoujście, through which $12 \%$ of the total gas supplies reached Poland, is becoming more and more important in the Polish import of gaseous fuel. Moreover, $17 \%$ of the gaseous fuel came from Germany and the Czech Republic (PGNiG Annual Report 2017).

The domination of Russian imports of natural gas, which has been present for many years, mainly due to favorable prices and good technological connections enabling their transport, is slowly becoming history. Thanks to the construction of several strategic infrastructure investments, Poles are diversifying their suppliers of blue fuel. A characteristic feature of the Polish natural gas transmission system is that it was built on an east-west line. The key element of the Polish gas system is the Yamal I pipeline, which carries imported natural gas from Russia to Poland. Unfortunately, there are no connections enabling the transport of this raw material on the north-south line, and this situation is slowly changing thanks to the gas terminal in Świnoujście. One of the most important measures to increase Poland's security in the gas sector was the investment consisting in the launching of a physical reverse flow on the Yamal gas pipeline. The development of the transmission network allowed gas to be transported to customers from various points of the transmission system.

Another component of Poland's energy balance are renewable energy sources, which are not yet used on a large scale and economically competitive with fossil fuel energy $(14.1 \%$ - share of energy from RES in obtaining primary energy at the end of 2017) (GUS 2017). In particular regions of the country the RES potential is diversified, which results from geographical and climatic differences. Currently, energy from renewable sources is used in the local energy sector primarily to increase local energy security, and especially to improve the energy supply in areas with a poorly developed energy infrastructure.

Supporting the development of these sources is a challenge for Poland in the face of changes imposed by the European Union.

An important issue affecting the state of Polish safety is the concept of a return to nuclear energy, which officially appeared in 2009. Donald Tusk's government began work on the launch of a nuclear power plant in this country. The original scenario assumed the opening of the first power unit in 2024, but the changes on the Polish political stage and problems with finding 
a strategic investor caused delays in the works. The current government has announced that the first power unit will be built after 2030 (Ciepiela 2018).

The Polish energy sector is facing a major challenge. It will have to meet the rapidly growing demand, while most of the assets used to produce heat and electricity need to be modernized. At the same time, new EU regulations are being introduced to limit climate change and secure energy supplies. On the other hand, energy development will depend on ensuring an adequate fuel mix.

\subsection{Hungary}

Hungary is a country with little potential for energy resources. The country's energy production is $45 \%$ of the total primary energy supply, so the small country is becoming more and more dependent on imports. Natural gas and oil are the largest sources of primary energy, while energy produced from the atom accounts for the largest share of electricity production. Brown coal is an important source of indigenous primary energy, which can be mobilized in a situation of energy crisis. At the beginning of the 1990s, as a result of a systemic change in Hungary, the majority of state-owned companies were transformed into smaller, private companies. As a result, many unprofitable coal mines, especially hard coal mines, were closed. Therefore, in 1993, hard coal production was abandoned, thus making Hungary dependent on imports of this raw material, mainly from the US. Brown coal mining currently amounts to 9.3 million tons per year, making the country self-sufficient in terms of energy production. Hungary's coal reserves are concentrated to a large extent in the over-Danube region and in the northern and north-eastern part of the country (Energy policies... 2017). It is worth noting that the continued use of coal is an important part of the national energy strategy of 2030.

Natural gas, as already mentioned, is Hungary's largest primary energy source. Its domestic production has been steadily declining for thirty years and currently amounts to 2 billion cubic meters per year. Such an amount allows about $1 / 5$ of the total demand for this raw material to be covered. The shortfall is compensated for by imports, most of which come from Russia. Unfortunately, the import dependence from Russia is enormous and amounts to $95 \%$. Diversification and the security of supply are to be achieved by gas connections with neighboring countries such as: Romania, Croatia, Bulgaria and Slovakia. These pipelines make it possible to trade gas with neighboring countries.

Due to the high dependence of the Hungarian electricity sector on gas, its storage is of key importance for security in this energy sub-sector. After the Ukrainian-Russian gas crisis in 2006 and 2009, the country has made the greatest effort among Central European countries to avoid Russian energy blackmail. This is reflected in 5 commercial gas storage facilities with a total capacity of 5.23 billion $\mathrm{m}^{3}$, which makes it possible to ensure $2 / 3$ of the annual demand. This gives Hungary one of the largest storage capacities in the region compared to the size of the market. 
Crude oil is the second largest source of primary energy after natural gas. The consumption of this raw material has been declining for many years, but it has recently increased slightly as a result of reduced gas consumption. As in the case of natural gas, "black gold" production in Hungary is small and is decreasing from year to year at the level of 900 thousand tons, meeting $11 \%$ of the demand. The Hungarian economy needs about 7.6 million tons of this raw material annually, so imports are necessary to meet the demand. Russia is the most important supplier of this carrier. Imports from this country account for $78 \%$ of the total supplies to Hungarian refineries. Another oil supplier is Iraq (15\%) and Slovakia (4\%). Despite the lack of access to the sea and thus a lack of an oil port, Hungary has an extensive transmission infrastructure. The main pipeline supplying crude oil to Hungarian refineries is the Druzhba pipeline. Oil supplies from Iraq are possible thanks to the reconstruction of the Adria pipeline running from the Omisaj port terminal in Croatia (Energy Policies... 2017).

Nuclear energy has been the main source of electricity generation in Hungary for more than 30 years, providing more than half (52\%) of the country's electricity production. The Hungarians have one Paks nuclear power plant with 4 PWR reactors, i.e. $500 \mathrm{MW}$ water-pressure reactors each. The Hungarians consider electricity generated at the Paks power plant to be a way to improve energy security while reducing carbon dioxide emissions. This position is confirmed by the National Energy Strategy 2030, which states that nuclear energy will continue to be an important part of the national energy sector. The Hungarian government has decided to extend the operation of the existing units and build two new power units in the Paks power plant. It is worth mentioning that in 2014, an agreement was signed between the Hungarian government and Rosatom for the construction of two new power units at the Paks power plant with a total capacity of 1200 MWe. They are to be opened in 2026 and 2027 and produce more energy than the existing four units, which will be closed between 2032 and 2037. The estimated investment cost is EUR 12 billion, EUR 10 billion of which is to come from a loan granted by Russia to Hungary (www.tvp.info...).

The construction of new units is the largest investment in the Hungarian energy sector in several decades and is therefore considered a priority project of the government. The modernization program of the old units will allow them to be operated for another 20 years until the new units become operational. It should be noted that the new units will be operational before the closure of the existing units, which will lead to a temporary increase in nuclear energy production, by limiting the import of energy for some time. In this way, Hungary is trying to prevent energy shortages that would await it after the closure of the Paks power plant.

The share of renewable energy in the Hungarian energy system has been increasing slightly over the last few years. The increased use of biomass for energy and heat production is the most important driver of RES growth. According to the EU Renewable Energy Directive of 2009, (2009/28/EC23) Hungary has to demonstrate a 13\% share of green energy in gross energy consumption by 2020 . As already mentioned, biomass is a source of more than $90 \%$ of total green energy production and other forms of RES have a marginal share. However, it is worth noting that solar energy has been the fastest growing energy source in recent years, although energy production from this source is low. Hungary's energy policy should change its orientation towards 
energy sources other than biomass in order to achieve the European Union's objectives in the future (Energy policies... 2017).

\subsection{Slovakia}

The Slovak Republic plays an important role in Central Europe as it brings the group together, as it is the only country bordering all members of the V4. Like the Visegrad countries discussed above, Slovakia has started to work on increasing its energy security and therefore supports energy architecture, which creates conditions for increasing energy self-sufficiency, diversifying the energy mix and increasing the production capacity of electricity using low-carbon technologies.

The Slovak energy basket has a balanced share of fossil fuels and nuclear energy in terms of energy consumption, which is as follows: natural gas $24 \%$, nuclear energy $24 \%$, coal $19 \%$, crude oil $22 \%$, renewable energy sources $10 \%$.

Slovakia, like Hungary, does not mine hard coal, which is entirely imported, mainly from Russia, Czech Republic and Poland. On the other hand, Brown coal is a significant energy raw material produced in Slovakia for 200 years. Domestic reserves of this energy carrier amount to 83 million tons. However, due to the specific geological structure in Slovakia, brown coal mining takes place underground and faces various difficulties, which increases production costs, which are higher than in neighboring countries. The Slovak mining industry, as in the countries of Central Europe, is experiencing a downward trend in production which is at 2 million tons (Energy Policies of IEA...2018). This is the main reason for the closure of unprofitable mines. However, the government wants to maintain brown coal production, which is to be supported by various support mechanisms (e.g. guaranteed purchase price) for this energy sector, as this raw material, apart from renewable energy sources, is the only domestic source of energy.

Slovak crude oil deposits are small and practically all used up. Production covers about $1.5 \%$ of the demand for this raw material. Imports take place via the Druzhba pipeline from Russia (5.8 million tons), which is the main and only supplier (2016) of this fuel to Slovak refineries.

Unlike other Central European countries, the consumption of natural gas in Slovakia is decreasing. Domestic resources are on the verge of exhaustion, meeting $2 \%$ of the demand. The future of gas production in Slovakia depends on the discovery of new deposits which will be economically and geologically efficient. As in the case of crude oil, the supplies of natural gas are made from Russia (87\%) as well as from the Czech Republic and Austria thanks to the reverse on interconnectors with these countries (Energy Policies... 2014). Slovakia also plays an important role as a transit country of the region through which Russian gas is transported to the neighboring Czech Republic and Hungary, but also to Western and Southern European countries: Germany, Austria, France, Italy, Slovenia and Croatia.

Due to the importance of gas as an energy source, Slovak security in the gas sector is strengthened by underground gas storage facilities, the capacities of which are constantly increasing. The current storage capacity is about 3 billion $\mathrm{m}^{3}$ and is able to satisfy up to $90 \%$ of annual gas 
consumption. Taking into account the storage capacity of other V4 countries, mainly Poland, which consumes 4 times more blue fuel and has the same storage capacity as the Slovak Republic, this small country not only strengthens its position among the countries with the highest ratio of storage capacity to domestic consumption of natural gas, but also ensures continuity in gas supply (Slovakia may... 2016).

Another very important source of energy in Slovakia is the energy coming from nuclear energy. This small, landlocked country has had two nuclear power plants for 50 years: Bohunice and Mochovce, each with two WWER 440 type reactors. It is worth noting that these power plants supply more than half of the electricity consumed in Slovakia (Country profile: Slovak Republic 2016). Moreover, Slovaks are completing the construction of two more power units at the Mochovce power plant, their opening is expected to take place in mid-2019 and 2020 - respectively for unit 3 and unit 4 (Is the completion of Mochovce... 2018).

In order to meet the requirements set by the EU within the framework of the adopted climate and energy packages of 2007 and 2014, the Slovak authorities decided to increase the share of RES in electricity consumption as a priority. The EU target of increasing green energy sources by 2020 in Slovakia is $14 \%$. Slovakia will achieve the target without any problems, thanks to hydropower and biomass. The hydropower sector is mainly based on large hydroelectric power plants, although small hydroelectric power plants (SHP), whose development is stimulated by subsidies, are also becoming more and more dynamic. Biomass has the highest energy potential of $120 \mathrm{PJ}$ of all Slovak RES. With the launch of the "green for households" program, which supports the production of heat and electricity from small domestic renewable energy systems, this form of energy production has been developed at the regional and local level. Renewable energy is promoted through a feed-in tariff. Energy companies are obliged to purchase energy from RES.

Other sources of green energy are of marginal importance for energy production. It is worth mentioning that while neighboring countries are investing in wind energy, in Slovakia its development was stopped in 2009, when investors could not obtain the consent of the grid operator to join it. The main reason for this is the position of the Slovak government, which considers wind energy to be unstable, with large fluctuations in production and not worth investing in (Jurcova 2017).

The main problem of the Slovak energy policy is the lack of a long-term vision and energy strategy. The government subsidizes unprofitable coal power plants in order to protect jobs. As a result, current policies and regulation of electricity prices have led to their highest level for the industry in the region.

Summing up the analysis of the energy systems of the Visegrad Group countries, it should be stressed that solid fuels dominate the energy balance of Poland and the Czech Republic, while gas is the main energy carrier in Hungary and Slovakia. Comparing the import dependency ratio in the analyzed region, it can be concluded that Slovakia is the country most dependent on imports of energy raw materials, as its own production is minimal, but on the other hand, the Slovak energy balance is the most diversified. Hungary, however, is the most vulnerable to problems with the continuity of supply due to its high share of natural gas in the energy production coming in over $95 \%$ from imports. 


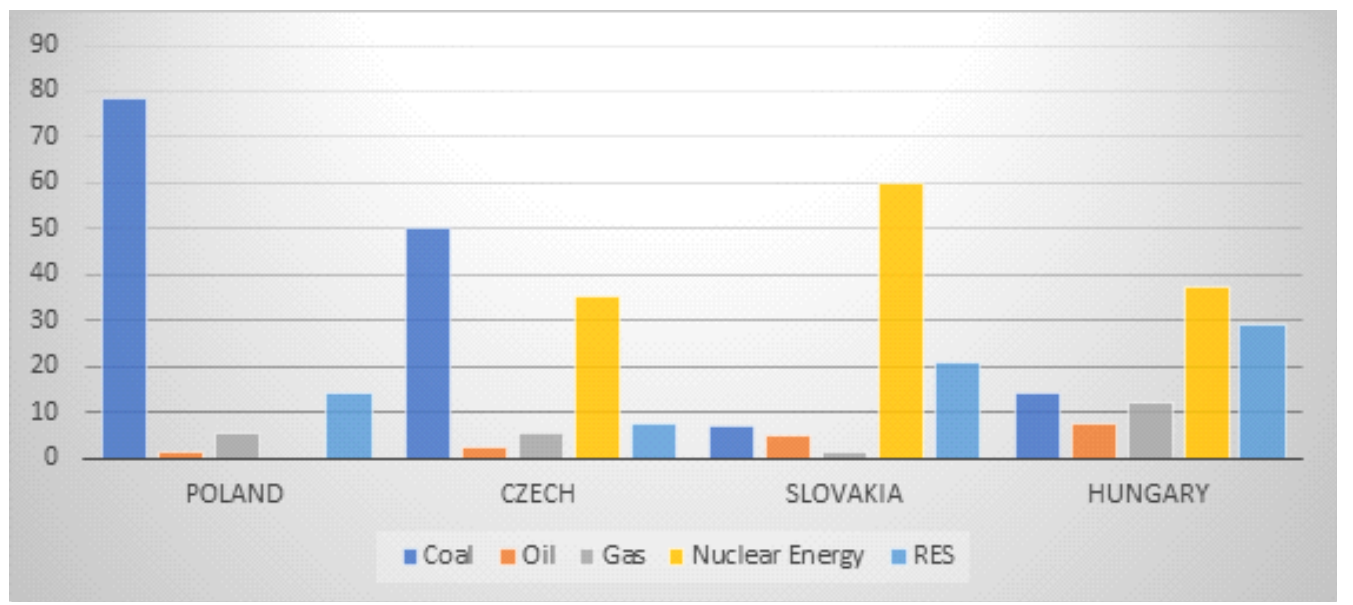

Fig. 1. Primary Energy production in the V4 countries in 2017 [\%] Source: own based on: www.export.gov, Energy Policies of IEA Countries

Rys. 1. Produkcja energii pierwotnej w krajach Grupy Wyszehradzkiej w 2017 r. [w \%]

It is worth noting that in all countries of the Visegrad Group there is a clear decrease in the production of energy from coal. Practically all countries have substantial resources of these raw materials, which in the past gave them energy self-sufficiency in this respect. They are slowly being replaced by other, more environmentally friendly hydrocarbons: natural gas and crude oil. In addition, in the three countries that have a nuclear power plant, their energy strategy places emphasis on increasing the share of energy from nuclear energy in the energy mix. This will be possible thanks to the modernization of the existing and the construction of new power units. However, the recent increase in the use of renewable energy sources is the result of the introduction of climate and energy packages by the European Union.

\section{Regional cooperation}

There is no doubt that an energy policy that shapes energy security is important for all Central European countries. The EU's current policy agenda is geared towards a comprehensive and integrated approach to energy and climate policy, while the decarbonization policy has taken on an important role. The European Council adopted progressive measures in the field of energy and climate at the end of 2008, under which it committed Member States to achieving the following targets by 2020 :

- A 20\% reduction in greenhouse gas emissions compared to 1990 levels;

$\checkmark$ Increase the share of renewable energy in all energy sources consumed to $20 \%$;

$\downarrow$ Increase of energy efficiency by $20 \%$. 
Six years later, the EU decision-makers adopted the Second Climate and Energy Package, which increases the previously adopted limits. Therefore, a further reduction of $20 \%$ of greenhouse gases is to take place, the share of RES in the total energy consumption is to be $27 \%$ and energy efficiency is to be increased by another $20-30 \%$. The targets are to be enforced in 2030. Unfortunately, EU measures to improve the climate force countries with high energy self-sufficiency to increase gas imports or to increase nuclear and renewable energy in the energy balance, and thus to reduce the production of energy from high-emission, domestic fossil fuels in the energy balance. The implementation of EU energy law is therefore a particularly difficult task for the countries in the region.

Due to excessive dependence on supplies of energy resources from one source (Russia), the growing importance of natural gas for the economy of most of the V4 countries, existing bottlenecks in the transmission infrastructure and the lack of an integrated regional energy market, these countries must take joint action to avoid the risks associated with the lack or shortage of energy resources. This makes the situation all the more dangerous due to the conflict in Ukraine, the transit country of Russian raw materials to Central Europe, which has been ongoing for several years. Russia, after launching the Nord Stream 2 pipeline intends to limit the transmission of natural gas to Europe via the existing transit route through Ukraine from 2019.

The aftermath of the Russian-Ukrainian crisis in the winter of 2009, during which many countries of the European Community had problems with ensuring the continuity of natural gas supplies, was the adoption of a series of measures to ensure that risk assessments were carried out and that appropriate preventive action plans and emergency plans were developed. The most important document ensuring the security of gas supply to Community countries is Regulation (EU) No 994/2010 (SOS) and Regulation 2017/1938, which focuses on strengthening regional cooperation, developing regional preventive action plans and contingency plans, as well as developing a solidarity mechanism to guarantee the security of the gas supply. The main beneficiaries of the Regulation are the countries of Central Europe and the Balkans. The text of the regulation defines three basic crisis states. The first is the early warning state - announced when there is reliable information indicating the possibility of an event hindering the sustenance of undisturbed gas supplies. The second is the alarm state - announced when there is a supply disruption or an unusually high demand for gas, e.g. due to very low temperatures. This state is introduced when it is possible to supplement the missing raw material with normal market mechanisms. In other words, it is assumed that energy companies and gas trading companies will be ready to sell their surpluses at the place where the shortages have occurred. The third and last one is the state of emergency. Its announcement makes it possible to apply the so-called non-market gas supply mechanisms. However, the use of this possibility must be preceded by the use of instruments provided for in the previous states and a visible lack of improvement in supplies. Then the EU Member States are obliged to guarantee the possibility of using cross-border transmission pipelines, if technically possible (Regulation (EU)... 2010).

After seven years, the European Parliament amended the SOS Regulation. EU decision-makers have come to the conclusion that there are still countries that may have serious problems in the event of gas supply disruptions. The new law provides for a solidarity mechanism, man- 
datory at the time in which the third crisis state is introduced. According to the new law, large consumers from one EU country will not receive gas if, in a neighboring EU country, the most needy consumers, who are at risk, have supply problems. The list of such recipients is the same in all EU countries and is limited to housing, hospitals, hospices or social assistance centers. No companies or schools are on the list (Regulation of the European... 2017).

Looking at the energy systems of the $\mathrm{V} 4$ countries, the conclusion can be drawn that the change in the huge dependence on natural gas supplies from Russia should be a priority element of cooperation between these countries. The most important investment project to change the import mix in Central European countries is the construction of the North-South Gas Corridor. The project will connect the LNG terminal in Świnoujście and the Baltic Pipe gas pipeline with the Czech Republic and Slovakia and Hungary with the Croatian LNG terminal on Krk Island. The terminal is to be the last link of the North-South Corridor. For almost twenty years, Croats have had the intention of building a gas port, but internal political animosities have prevented this important project from being carried out. At the end of 2017, the European Commission allocated EUR 102 million for this project, and the Croatian government adopted a special law concerning the construction of the terminal, which is supposed to significantly simplify the administrative procedures related to the construction of this unit. The terminal on the island of Krk will be, similarly to the Lithuanian Klaipeda, a floating vessel (FSRU) with a capacity of 2.6 billion cubic meters per year, with the possibility of its expansion by an onshore terminal with a capacity of 7 billion cubic meters per year (Nieczypor 2018).

The corridor consists of a number of bilateral interconnectors and national gas pipelines, most of which already exist and others are at different stages of planning or construction. This form of investment organization is of great importance for their physical implementation. Firstly, it allows for the independent implementation of individual elements of the Corridor and makes the sources of financing more dispersed, as the costs of individual investments are divided into many different entities, which makes them easier to bear. Moreover, the investment, as an instrument significantly strengthening the energy market of the region, has obtained the status of a "Project of Community importance" granted by the European Commission.

The first interconnections built in Central Europe were not reversible, but the EU obliged system operators to implement reverse flow, especially at border interconnectors, as this increases the security of the gas supply. The implementation of reverse flow in the West-East direction has made it possible to deliver larger volumes of gas available on demand to the V4 countries. One such connection was the German-Czech Republic-Slovakia gas interconnection, where the flows after its commissioning were higher from the west via Nord Stream and its Opal and Gazelle branches than from the east from Russia via Ukraine via the Yamal pipeline. Another important interconnection, which will enable the flow of gas from Croatia to Hungary and Romania, is expected to be built in 2019. Pipelines, with gas flowing from Hungary to Croatia and Romania are currently in operation. The reverse flow is particularly important for Hungary, which is interested in the supply of gas produced in Croatia and, in the future, in the supply of gas from the LNG terminal. For Hungary, the prospect of launching this reverse is an opportunity for the real diversification of gas supply sources. The lack of reverses at the interconnectors with Romania and Croatia condemned Hungary to close gas cooperation with Russia. Obtaining alternative 


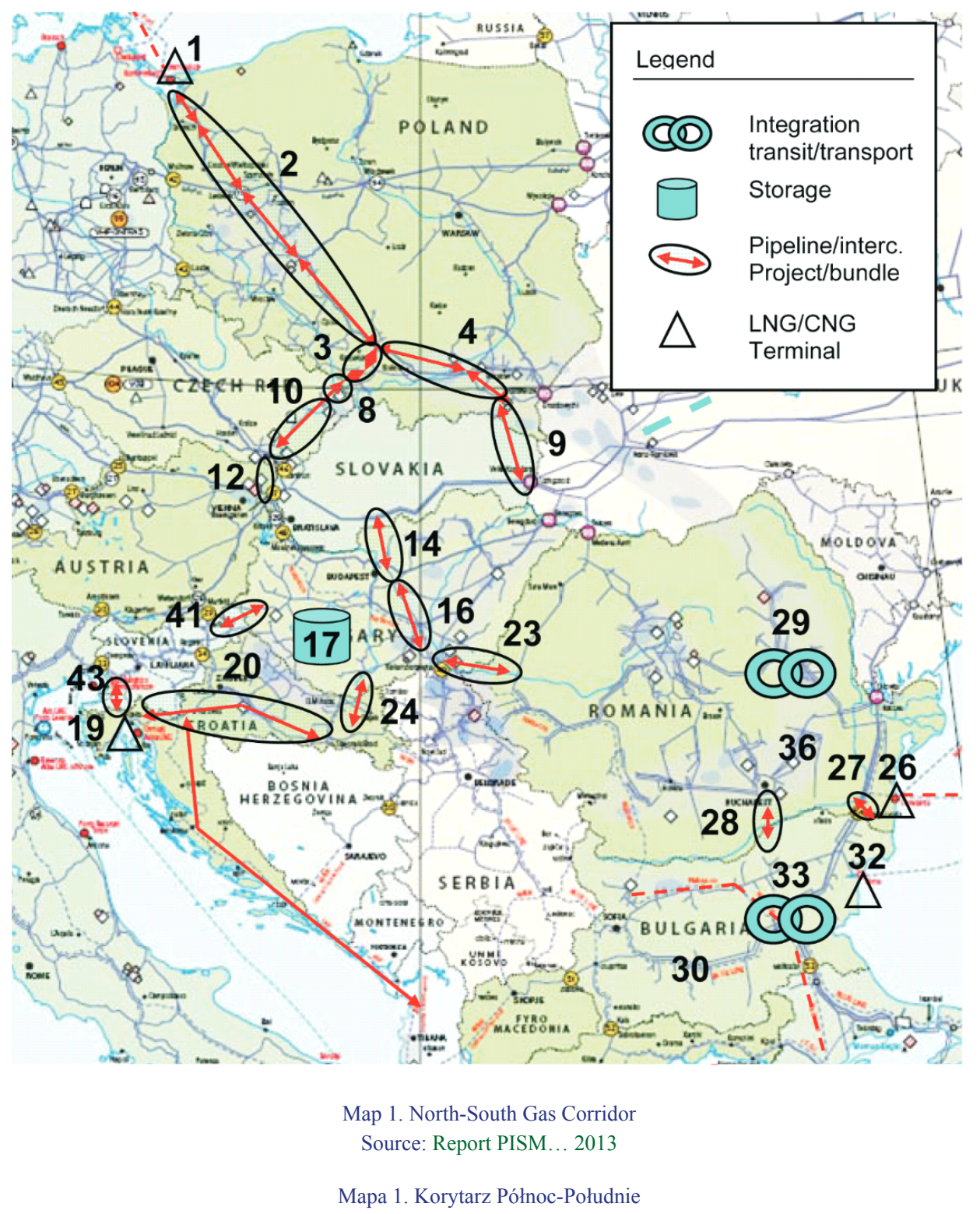

sources of gas supplies is of key importance for Hungary in view of negotiations on a new gas contract with Gazprom after 2021 (Sadowski 2017).

An important factor that accelerated the development of new projects in the region was the EU's increased financial commitment. In addition to the existing TEN-E (Trans - European Networks for Energy) support instrument, an investment plan - EEPR (European Energy Program for Recovery) - was established in 2009, investing more than EUR 2 billion in gas and electricity interconnection projects (Pronińska 2013). 
TABLE 1. Joint gas investments of V4 countries

TABELA 1. Wspólne inwestycje gazowe państw V4

\begin{tabular}{|l|l|c|c|c|}
\hline \multirow{2}{*}{ INVESTMENT } & \multicolumn{1}{|c|}{ PLACE } & $\begin{array}{c}\text { LENGTH } \\
(\mathrm{KM})\end{array}$ & $\begin{array}{c}\text { COST } \\
{[\mathrm{mln} \text { euro }]}\end{array}$ & $\begin{array}{c}\text { THE START } \\
\text { DATE }\end{array}$ \\
\hline \multirow{3}{*}{ North-South Corridor } & Poland-Czech Republic & 112.4 & 546 & 2020 \\
\cline { 2 - 5 } & Poland-Slovakia & 165 & 524 & 2021 \\
\cline { 2 - 5 } & Slovenia-Hungary & 113 & 140 & 2021 \\
\hline \multirow{2}{*}{ Reversal of interconnectors } & Austria-Czech Republic & 61 & 50 & 2020 \\
\cline { 2 - 5 } & Croatia-Hungary & 308 & 370 & 2019 \\
\hline LNG Terminal & Croatia-island of Krk & - & 384 & 2019 \\
\hline
\end{tabular}

Source: own work.

One of the last system interconnections within the North-South Corridor is the commencement of the construction of a gas connection between Poland and Slovakia. It is worth mentioning that Slovakia was the European country most affected by the gas crisis in 2009. It was completely cut off from imported gas supplies. Despite the fact that the country had strategic reserves, there was no infrastructure to transport the raw material from west to east, which made it impossible to supply the eastern regions of Slovakia. Moreover, there were no interconnector mainstreams between the neighboring countries, which meant that, despite the willingness to grant State aid, the neighboring countries were powerless. This interconnection is therefore necessary to enhance the regional security of the supply, to integrate gas markets in the region and to prevent a similar situation from arising in the future. The interconnector will make it possible to diversify gas sources in Central and Eastern Europe. As a result of the project, the V4 countries will gain direct access to new sources of gas from the north, i.e. gas from the Polish LNG terminal and from Norway after the construction of the Baltic gas pipeline. Moreover, it will be possible to transport gas from the southern direction through the Slovakia-Hungary and Croatia-Hungary interconnections, among others, from the planned liquefied gas terminal on the island of Krk (Good information... 2018).

Another project currently being implemented concerns the increase of transmission capacity at the Poland-Czech Republic interconnector, moreover, thanks to the modernization and construction of new transmission systems in both countries, and the reverse flow, i.e. gas will flow from Poland to the Czech Republic, will also be possible.

It is worth stressing that not all countries in the region want or can push Russian gas out of their import basket. They are therefore trying to diversify the supply routes of the Russian raw material. The Czechs draw Russian gas from the German Opal pipeline, which connects with Nord Stream, and further from the Gazella pipeline and the Hungarians from Austria via the HAG pipeline.

The diversification of gas suppliers through new gas pipelines and terminals for the off-take of liquefied gas undoubtedly increases energy security in the region. For several years, the gas markets in Central European countries have been undergoing a profound transformation. By 
separating sales and the transport of gas, freeing gas prices as well as implementing a new tariff model, the gas systems in these countries are liberalized. Another element of the creation of a common gas market in Europe is the physical integration of Central European markets through the construction of interconnections and the implementation of mechanisms to improve the free flow of gas in the region. However, the creation of a regional market in this part of Europe is extremely difficult due to several significant aspects. Firstly, the gas markets in individual countries are at different levels of development and have different specificities. Secondly, their deeper integration may not be possible due to fears of reduced transit revenues and the desire of the countries to maintain control over gas prices for individual consumers.

The described infrastructure measures within the North-South Corridor play a very important role in ensuring the energy security of the region. First of all, they serve the diversification of natural gas suppliers and change its transport routes from the existing unidirectional transmission system created during the times of the USSR to a transfer system running from north to south and from the west to the east of Europe.

\section{Summary}

The structure and organization of the energy market of each country largely depends on its geological and geographical conditions. The size of energy resources currently determines the economic condition and position of the state on the international arena. They also provide a basis for the development of an advanced economy, hence it is one of the most important factors influencing the country's energy security.

The common experience of communism and liberation from it contributed to similar, social and economic transformations of the 1990s, although taking place at different paces, in the countries of Central Europe. The communist legacy in the energy sector of the countries of the region is strongly dependent on Russia, which in President Putin's policy has become a fundamental tool of pressure and, as shown by the history, of blackmail towards Central and Eastern Europe. The scale of the threat to the energy security of the countries of the region was demonstrated by the crisis with Ukraine caused by Russia in 2009.

Almost ten years after the emergence of Russian energy blackmail against Ukraine, the fragmentation of Europe's energy security environment has decreased. The Visegrad Group countries, despite the fact that they still have a long way to go to match the countries of Western Europe, have done a great deal of work towards improving the energy security of the region. The introduction of appropriate legal regulations at the EU level and EU financial assistance in the construction of adequate energy infrastructure have contributed to this state of affairs.

It is to be hoped that the recent infrastructure investments in the energy sector will make political decision-makers from Central European countries aware that, combined with common objectives, they have much a greater bargaining power at the European Community forum and 
greater negotiating power during talks with Russia as part of the extension of gas contracts (e.g. easing or abolishing "take or pay" contractual clauses).

The construction of infrastructure connecting the energy systems of the V4 countries is the first phase of creating an integrated regional energy market. The emerging market will therefore be an important consumer of natural gas and will also be attractive for LNG producers thanks to liquefied natural gas terminals in Poland and Croatia. Connected by new infrastructure and regulations, the market will increase the importance of the Central European region in the supply chain and improve the security of supply.

\section{References}

Annual Report POPIHN 2017, Warsaw 2017, pp. 100.

ASCARI, S. 2013. The gas target model for the Visegrad 4 region. Conceptual Analysis. „Raport OSW”, Warsaw.

CEZ, a. s. - Nuclear Power Plants, 2018. [Online] http://www.cez.cz/en/power-plants-and-environment/ nuclear-power-plants.html [Accessed: 2019-08-29].

CIEPIELA, D. 2018. The Polish wave power plant will be built after 2030 (Polska elektrownia jądrowa powstanie po $2030 \mathrm{r}$.). [Online] https://energetyka.wnp.pl/polska-elektrownia-jadrowa-powstanie-po2030-r,320551_1_0_2.html [Accessed: 2019-08-29] (in Polish).

Country profile: Slovak Republic, 2016. [Online] https://www.oecd-nea.org/general/profiles/slovak_republic.html [Accessed: 2018-08-30].

ĆWIEK-KarPowicZ, J. and KaŁAN, D. 2013. North South Gas Corridor Geopolitical Braekthrough in Central Europe "Report PISM", Warszaw.

Czech Republic Energy Overview 2018. [Online] https://www.export.gov/article?id=Czech-Republic-Energy [Accessed: 2018-08-12].

Good information in the case Poland-Slovakia gas pipeline 2018 (Dobre informacje w sprawie gazociagu Polska-Slowacja 2018). [Online] https://gazownictwo.wnp.pl/dobre-informacje-w-sprawie-goazociagu-polska slowacja,322467_1_0_0.html [Accessed: 2018-09-10] (in Polish).

Energy Policies of IEA Countries, The Slovak Republic Reviev 2018, 2018, IEA, pp. 172.

Energy policies of IEA Countries. Hungary Reviev 2017, 2017, IEA, pp.176.

Energy Policies of the Slovak Republic, 2014, Ministry of Economy of the Slovak Republic, pp.110.

Gas Networks 2018. [Online] http://www.ote-cr.cz/statistics/long-term-balance/gas-networks/gas-networks [Accessed: 2018-08-13].

[Online] http://geoportal.pgi.gov.pl/surowce/energetyczne/wegiel_kamienny/ [Accessed: 2018-08-12].

[Online] https://stat.gov.pl/obszary-tematyczne/srodowisko-energia/energia/energia-ze-zrodel-odnawialnych-w-2017-roku,10,1.html [Accessed: 2018-10-01].

[Online] https://www.mpo.cz [Accessed: 2018-08-11].

[Online] https://www.tvp.info/37531594/awaria-bloku-elektrowni-atomowej-na-wegrzech [Accessed: 2018-08-28].

Is the completion of Mochovce nuclear plant close? 2018. [Online] https://spectator.sme.sk/c/20868614/ is-the-completion-of-mochovce-nuclear-plant-close.html [Accessed: 2018-09-01].

JóźWIK, T. 2017. Getting closer to become independent of Gazprom. States give us gas (Coraz bliżej uniezależnienia się od Gazpromu. Stany dodają nam gazu) [Online] http://forsal.pl/artykuly/1087112,corazblizej-uniezaleznienia-sie-od-gazpromu-stany-dodaja-nam-gazu.html [Accessed: 2018-08-28] (in Pol$i s h)$. 
JURCOVA, V. 2017. The Slovak energy transition - decarbonisation and energy security. [Online] https:// energytransition.org/2017/05/the-slovak-energy-transition-decarbonisation-and-energy-security/ [Accessed: 2018-09-01].

NIECZYPOR, K. Alea Iacta Est, The battle for the LNG terminal in Croatia (Alea iacta est, czyli bitwa o terminal LNG w Chorwacji). [Online] https://www.energetyka24.com/gaz/alea-iacta-est-czyli-bitwao-terminal-lng-w-chorwacji [Accessed: 2018-09-06] (in Polish).

Small Statistical Year 2017, 2017 (Maty Rocznik Statystyczny 2017), GUS, Warsaw, 539 pp. (in Polish).

PopŁawsKi, K. 2016. Role of Central Europe in the German economy. Political consequences, "Raport OSW", Warsaw, p. 4.

PRONIŃSKA, K. 2013. Impact of energy cooperation of Central European countries on regional energy security and energy policy of the EU. Zeszyty Natolińskie No. 51, p. 53.

Regulation (EU) No 994/2010 of the European Parliament and of the Council of 20 October 2010 concerning measures to safeguard security of natural gas supply and repealing Council Directive 2004/67/EC (Official Journal of the European Union L. 295/1 of 12.11.2010).

Regulation of the European Parliament and of the Council No 2017/1938 of 25 October 2017 concerning measures to safeguard security of natural gas supply and repealing Council Directive 994/2010 (Official Journal of the European Union L. 280/1 of 28.10.2017).

SADOWSKI, A. 2017. Reverse flow on the Hungarian-Croatian gas connector - breaking the deadlock, “OSW Analysis”. (Rewers na węgiersko-chorwackim łaczniku gazowym - przełamanie-impasu „Analiza OSW") [Online] https:osw.waw.pl/pl/publikacje/analizy/2017-06-28/rewers-na-wegiersko-chorwackim-laczniku-gazowym-przelamanie-impasu [Accessed: 2018-09-01] (in Polish).

Slovakia may have new underground gas storage 2016. [Online] https://spectator.sme.sk/c/20278327/slovakia-may-have-new-underground-gas-storage.htm.1 [Accessed: 2018-09-01].

State Energy Policy of the Czech Republic 2014. Ministerstvo Prumyslu a Obchodu, Prague, pp. 159.

[Online] https://euracoal.eu/info/country-profiles/czech-republic/ [Accessed: 2018-05-01].

\section{Regionalna współpraca w zakresie bezpieczeństwa gazowego w Europie Środkowej}

\section{Streszczenie}

Rola i znaczenie bezpieczeństwa energetycznego wzrasta wraz z rozwojem cywilizacyjnym, którego nieodłącznym elementem stało się zapotrzebowanie na energię oraz jej nośniki. W artykule poruszono kwestię współpracy w zakresie bezpieczeństwa energetycznego w Europie Środkowej w momencie finiszu prac nad Korytarzem Północ-Południe, który zmienia dotychczasową architekturę gazową w regionie. Dla lepszego zrozumienia sytuacji panującej w regionie analizie poddane zostały systemy energetyczne państw Grupy Wyszehradzkiej, tożsamej z regionem Europy Środkowej, według definicji Banku Centralnego i OECD. Biorąc pod uwagę historyczne i geopolityczne powiązania państw Grupy Wyszehradzkiej, istot- 
ne znaczenie ma stworzenie wspólnego rynku gazu. Fizyczne połączenie systemów gazowych ogromnie podnosi bezpieczeństwo energetyczne w tym regionie. Ponadto dzięki budowie terminali LNG w Polsce i Chorwacji, możliwa stanie się dywersyfikacja nie tylko szlaków, ale także źródeł dostaw tego ważnego surowca.

SŁOWA KLUCZOWE: bezpieczeństwo energetyczne, polityka energetyczna UE i Grupy Wyszehradzkiej, rynek gazu ziemnego 